Egyptian Journal of Rabbit Science, 29 (1): 1-21(2019)

\title{
INFLUENCE OF INGESTION OF NANO-SELENIUM ON GROWTH PERFORMANCE, ANTIOXIDATIVE AND MUTAGENICITY STATUS IN SOMATIC CELLS OF NEW ZEALAND WHITE RABBITS
}

\author{
A.S.O El-Badry '; Mahrousa Mohamed Hassanane ${ }^{2}$; G.A.G. Mosalm ${ }^{1}$; \\ Ekram Salah Ahmed ${ }^{2}$ and T.A. El-Aasar ${ }^{1}$ \\ 1 Rabbit, Turkey and Water Fowl Breeding Res., Dep., Anim., Ins., Egypt. \\ 2 Department of Cell Biology, National Research Centre, Egypt.
}

Heat stress is one of many problems facing the modern rabbit production. This study was planned to ascertain the effect of ingestion of different sources of selenium on alleviation of heat stress in growing rabbits, productive Performance, mutagenicity in somatic cells and oxidative status in rabbits was used as indices for the study. A total number of 60 unsexed weaned New Zealand White (NZW) rabbits, aged

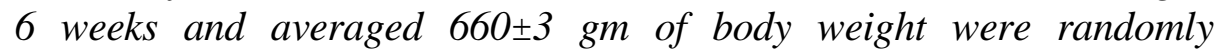
distributed into four experimental groups (15 rabbits of each). The first group was used as a control and received orally $2 \mathrm{ml}$ of saline solution every day, while the $2 \mathrm{nd}$, 3rd and 4th groups were received orally selenium three sources of nano, organic and inorganic, respectively, at level of $0.3 \mathrm{mg} / \mathrm{kg}$ body weight every day using stomach tube. The experiment continued for 6 weeks. The sources of selenium were dissolved in $2 \mathrm{ml}$ of saline solution. Heat stress was induced by exposure of all rabbit groups to a temperature of $38^{\circ} \mathrm{C}$ for 4 hours daily.

The results demonstrated that heat stress significantly depressed body weight gain, feed intake, feed conversion ratio, empty carcass (\%), dressing \% and abdominal fat weight, while feeding nano-Se or organic form clearly alleviated these negative effects of heat stress as compared to those fed inorganic Se form and control groups. Also, heat stress caused increase in chromosomal aberrations, as well as it decreased the total nucleic acids and protein contents. In addition, nano and organic selenium treatments caused to decrease in all studied parameters relative to heat stress compared to those of inorganic Se form and control groups. In addition, ingestion of nano and organic source of 
selenium by rabbits caused significant improvement in total antioxidant capacity in blood and alleviated the negative effects of heat stress via reducing the malondialdehyde content in blood.

In conclusion, feeding of nano and organic source of selenium enhance productive performance of rabbits by improving the antioxidative properties under heat stress. This effect could be due to their ability in decreasing frequencies of chromosomal aberrations and decreasing total nucleic acids and protein contents. The use of nano-Se or organic Se form appeared to be more significant than inorganic Se in alleviation the undesirable effects of heat stress.

Keywords: Selenium forms, oxidative stress, chromosomal aberrations,

Heat is one of the most important stressors affecting animal production. The most obvious limitation of rabbit production is in regions with a hot climate. The thermo-neutral zone temperature in rabbits is around $18-21{ }^{\circ} \mathrm{C}$ (Habeeb et $a l .$, 1998). Thus, when rabbits are exposed to elevated ambient temperatures (Ta) imbalances are induced in their body temperature (Habeeb et al., 1999), at high temperature $\left(30^{\circ} \mathrm{C}\right)$ the appetite is depressed, the productive and reproductive performances are impaired and the resistance to disease is decreased (Okab et al., 2008). Heat stress is one of the wide varieties of factors, which caused oxidative stress in-vivo (Kumar and Kumar, 2011), during summer and/or in the tropics. Reactive oxygen species (ROS), is consider the main cause of oxidative stress, and are constantly generated in-vivo as an integral part of metabolism. Reactive oxygen species can damage the cells, including damage to DNA, lipid membranes and proteins, if the production of reactive oxygen species be more than usual. Selenium is a dietary essential trace mineral having many of biological functions in the living system. Selenium (Se) plays a central role in enzymatic defense pathways against oxidative damage in tissues.

Nano-Se has attracted widespread attention due to its high bioavailability and low toxicity, because nanometer particulates exhibit novel characteristics, such as great specific surface area, high surface activity, a lot of surface active centers, high catalytic efficiency and strong adsorbing ability and low toxicity (Wang et al., 2007). Since surface area-to-volume ratio increases with decreasing the particle size, selenium nanoparticles have high biological activity (Zhang et al., 2005), including anti-hydroxyl radical property (Gao et 
al., 2002) and a protective action against the oxidation of DNA (Huang et al., 2003). Nano-Se possesses higher efficiency than selenite, selenomethionine, and (Zhang et al., 2005) and regulating selenoenzymes and exhibit lesser toxicity (Zhang et al., 2001).

So, this study was designed to investigate the effect of different sources selenium on alleviation of heat stress in growing rabbits. Productive performance, chromosomal aberrations and oxidative status in rabbits were used as indices for the study.

\section{MATERIALS AND METHODS}

The present study was carried out in private rabbits farm, near ElNobariah city, El-Beherah Province, Egypt,

\section{Flock management}

The rabbits were housed in galvanized wire $(50 \times 50 \times 45 \mathrm{~cm})$ cages provided with feeders and automatic watery system, in a well-ventilated building, where the environmental temperature ranged between $23.6{ }^{\circ} \mathrm{C}$ to 34.4 ${ }^{\circ} \mathrm{C}$ while, humidity was from 40.4 to $70.2 \%$. A period of $14-16$ hours of day light was provided. Feed and clean fresh water were available all time ad libitum for all rabbit groups during the experimental period. The commercial basal pelleted diet was formulated to cover the nutrient requirements and contained $17 \%$ crude protein, $13.8 \%$ crude fiber, $2.3 \%$ fat and $2500 \mathrm{kcal}$ digestive energy $/ \mathrm{kg}$ diet. All nutrients, essential amino acids, minerals and vitamins in the experimental diets were adjusted according to the rabbit requirements of NRC (1977). Manure was dropped from the cages on the floor and were collected and removed daily. All rabbits were kept under the same managerial, hygienic and environmental conditions during April and May (2017).

Preparation and characterisation of nanoselenium (Nano-Se).

The chemicals used in present study were purchased from Sigma-Aldrich Company (Los Angeles, USA). Nanoselenium was prepared using chemical co-precipitation method according to Zhang et al., (2011). X-ray diffraction (XRD) and transmission electron microscopy (TEM) were used for characterization of selenium-nano particles (Se-NPs). Transmission Electron Microscopy (TEM) showed that the size of elemental selenium was 20-50 nm. 


\section{Experimental design}

A total number of 60 unsexed weaned New Zealand White (NZW) rabbits, aged 6 weeks and averaged $660 \pm 3$ gm body weight were randomly distributed into four experimental groups (15 rabbits of each). Each treatment was divided into three equal replicates, each of 4 rabbits. The $1^{\text {st }}$ group (control group) received $2 \mathrm{ml}$ of distilled water orally every day, while the $2^{\text {nd }}, 3^{\text {rd }}$ and $4^{\text {th }}$ groups were orally received three forms of selenium, nano, organic (Sel$\mathrm{Plex}^{\mathrm{TM}}$ ) and inorganic (Sodium selenite) forms respectively at level of 0.3 $\mathrm{mg} / \mathrm{kg}$ body weight every day using stomach tube during the experimental period. The experiment continued for 6 weeks. The test ingredient was dissolved into $2 \mathrm{ml}$ of distilled water and administered orally in the morning, before feeding. Heat stress was induced through exposure of all rabbit groups to a temperature of $38{ }^{\circ} \mathrm{C}$ daily for 4 hours starting from 10.00 A.M. to 14.00 P.M. using gas heaters then the rest of the day were kept at natural temperature.

\section{Productive performance and Carcass measurements:}

Animals were weighed individual at the beginning of the experiment (6 weeks) and every two weeks thereafter up to 12 weeks. Feed intake was recorded individually each 14-d intervals and feed conversion ratio was calculated. Feed conversion ratio was calculated as feed consumed (g) divided by weight gain $(\mathrm{g})$ and economic efficiency was calculated according to Raya et al. (1991).

At the end of the experimental, three rabbits from each group were slaughtered to study characteristics of carcass. Carcass weight was considered as the weight of fore part, intermediate part and hind part. The weight of additional edible parts included the weight of liver, heart and kidneys. Dressed meat weight was obtained as the sum of the carcass weight and the weight of the edible parts. Dressing yield was calculated by dividing the dressed meat weight by preslaughter weight and expressed as a percentage. Three tissue samples from hind leg muscle of rabbit of each treatment were stored at $4{ }^{\circ} \mathrm{C}$.

The samples were subjected to the analysis for determination of moisture, crude protein, ether extract (fat) and ash according to AOAC 2001 and water holding capacity (WHC) was estimated according to Nakamura and Katoh, 1985 after centrifugation of $1 \mathrm{~g}$ of muscle to 4 minutes at $1,500 \mathrm{x} \mathrm{g}$. The remaining water after centrifugation was quantified by drying the sample over night at $70^{\circ} \mathrm{C}$. The WHC was calculated as follows: (sample weight after 
centrifugation - weight after drying) x 100 / initial weight. Se concentrations in meat were measured by atomic absorption spectro photometry according to the method of Brown and Watkinson (1977). The samples were prepared for measuringby ultrasound sonication with a mixture of nitric acid and hydrogen peroxide. Lipid oxidation in minced samples of hind leg meat was measured by the thiobarbituric acid method according to Piette and Raymond (1999) at 0, 6 and 12days from refrigerated time storage. Thiobarbituric acid-reactive substances (TBARS) were expressed in $\mathrm{mg}$ of malondialdehyde per $\mathrm{kg}$ muscle.

\section{Collection of blood samples}

At the end of the experiment, during slaughter test, $5 \mathrm{ml}$ of blood samples were taken at 09:00 am from the marginal ear vein under vacuum in clean tubes, centrifuged and serum is separated, kept on $-20^{\circ} \mathrm{C}$ to perform some relevant analysis such as Oxidant/ antioxidant markers including malondialdehyde and total antioxidant were estimated using commercial kits (Bio Merieux, France) according to the procedure outlined by the manufacturer.

\section{Assays to detect chromosomal aberrations:}

During slaughter test the bone marrow tissue was subjected to colchicines treatment $(0.5$ solution $0.1 \mathrm{ml} /$ culture $)$, hypotonic treatment ( $\mathrm{KCI}$, $5.6 \mathrm{~g} / 1$ ), fixed in acetomethanol, spread, and stained by Giemsa stain, in 6.8 phosphate buffer (Evans,1987). To analyze the frequency and type of chromosomal aberrations, 100 well spread metaphases were analyzed under the microscope for each rat in either the therapeutic or double therapeutic doseexposed animals. The chromosomal aberrations observed were classified as follows: Structural chromosomal aberrations which include gap, break, deletion and centromeric attenuation.

\section{Determination of nucleic acid contents and total protein in tissue:}

Quantitative changes in nucleic acid were determined by the method described by Bregman (1983). One gram of liver was homogenized in 5\% trichloroacteic acid, centrifuged and boiled in a mixture of absolute ethanol and ethanol/ether mixture 3:1. After centrifugation, trichloroacteic acid 5\% was added. The supernatant was separated to be ready to be quantified using specific reagents for DNA (DPA reagent) and RNA (orcinol reagent). Protein is estimated in tissue using commercial kits according to Lowry et al. (1951). 


\section{Statistical analysis:}

Data were statistically analyzed according to Snedecor and Cochran (1982) using SAS (2001) Computer Program as the following fixed model:

$$
\mathrm{Y}_{\mathrm{ijk}}=\mu+\mathrm{Ti}+\mathrm{Rj}+\mathrm{e}_{\mathrm{ijk}}
$$

Where: $\mathrm{Y}_{\mathrm{ijk}}=$ the observation; $\mu=$ Overall mean; $\mathrm{Ti}=$ Effect of treatments $(\mathrm{i}=$ $1, \ldots 4) ; \mathrm{Rj}=$ Replicates $(\mathrm{j}=1,2,3)$; $\mathrm{e}_{\mathrm{ijk}}=$ Random error component assumed to be normally distributed.

Duncan's multiple range tests was performed (Duncan, 1955) to detect significant differences among means

\section{RESULTS AND DISCUSSION}

\section{Productive performance:}

The effect of different Se sources on live body weight (LBW) and total body weight gain (TBWG) at different ages are presented in Table 1. Results show that LBW values were significantly the highest with rabbits received Nano-Se followed by the rabbits received organic Se as compared to the other treatment groups. The same trend was noted in body weight gain. These results are in agreement with Ebeid et al. (2012) who showed that feeding rabbits on diets supplemented with organic Se at levels from 0.15 up to $0.30 \mathrm{ppm}$ had superior live body weight and daily weight gain compared with the control group. However, are in disagreement the present results, with Dokoupilova et al. (2007) who found that body weight gain of growing rabbits did not significantly affect by adding dietary selenium.

The improvement in body weight gain in these groups may be due to that nano-Se and organic Se are absorbed well from the gut compared to the other forms of Se. On the other side, the possible reasons are that Se nanoparticles may make selenium more effective in stimulating of the thyroid gland (T3) (Edens, 2002), where Se is an important auxiliary factor for the key enzyme of 5-deiodinase. The iodothyronine deiodinase enzyme convert the pro-hormone thyroxine (T 4) to the active form of triiodothyronine (T3). Triiodothyronine is a main hormone that regulates growth by controlling the body's energy and protein anabolism (Preter, 2000).

Feeding of different Se sources had no significant effect on total feed intake at all ages, except at 6-8 week of age. Feed conversion ratio was significantly the lowest with rabbits received nano selenium followed by the rabbits received 
Table 1: Effect of different sources of dietary Se on live body weight and total weight gain of growing NZW rabbits exposed to heat stress

\begin{tabular}{|c|c|c|c|c|c|}
\hline \multirow[t]{2}{*}{ Items } & \multicolumn{5}{|c|}{ Treatment groups } \\
\hline & Control & Nano-Se & Organic Se & Na-Se & Sig. test \\
\hline \multicolumn{6}{|c|}{ Live body weight (g) } \\
\hline $6 \mathrm{Wks}$ & $\begin{array}{c}660.10 \\
\pm 1.03\end{array}$ & $\begin{array}{c}658.90 \\
\pm 1.59\end{array}$ & $\begin{array}{c}659.60 \\
\pm 1.15\end{array}$ & $\begin{array}{c}659.20 \\
\pm 1.38\end{array}$ & NS \\
\hline $8 \mathrm{Wks}$ & $\begin{array}{c}869.90^{\mathrm{c}} \\
\pm 5.55\end{array}$ & $\begin{array}{c}959.30^{\mathrm{a}} \\
\pm 6.08 \\
\end{array}$ & $\begin{array}{c}948.70^{\mathrm{a}} \\
\pm 5.03\end{array}$ & $\begin{array}{c}921.70^{\mathrm{b}} \\
\pm 7.52 \\
\end{array}$ & $*$ \\
\hline $10 \mathrm{Wks}$ & $\begin{array}{c}1135.00^{\mathrm{c}} \\
\pm 6.93 \\
\end{array}$ & $\begin{array}{c}1246.90^{\mathrm{a}} \\
\pm 7.48 \\
\end{array}$ & $\begin{array}{c}1227.50^{\mathrm{a}} \\
\pm 6.03\end{array}$ & $\begin{array}{c}1148.90^{b} \\
\pm 6.38\end{array}$ & $*$ \\
\hline $12 \mathrm{Wks}$ & $\begin{array}{c}1381.70^{\mathrm{b}} \\
\pm 8.44\end{array}$ & $\begin{array}{c}1524.40^{\mathrm{a}} \\
\pm 5.50\end{array}$ & $\begin{array}{c}1495.80^{\mathrm{a}} \\
\pm 4.50\end{array}$ & $\begin{array}{c}1420.20^{\mathrm{b}} \\
\pm 8.33\end{array}$ & $*$ \\
\hline \multicolumn{6}{|c|}{ Total body weight gain (g) } \\
\hline 6-8 Wks & $\begin{array}{c}209.80^{\mathrm{c}} \\
\pm 6.25 \\
\end{array}$ & $\begin{array}{c}300.40^{\mathrm{a}} \\
\pm 6.18 \\
\end{array}$ & $\begin{array}{c}289.10^{\mathrm{a}} \\
\pm 8.44 \\
\end{array}$ & $\begin{array}{c}262.50^{\mathrm{b}} \\
\pm 6.70\end{array}$ & $*$ \\
\hline $8-10 \mathrm{Wks}$ & $\begin{array}{c}265.10^{b} \\
\pm 6.99 \\
\end{array}$ & $\begin{array}{c}287.60^{\mathrm{a}} \\
\pm 8.74 \\
\end{array}$ & $\begin{array}{c}278.80^{\mathrm{a}} \\
\pm 5.29 \\
\end{array}$ & $\begin{array}{c}263.20^{\mathrm{b}} \\
\pm 6.85 \\
\end{array}$ & $*$ \\
\hline $10-12 \mathrm{Wks}$ & $\begin{array}{c}246.70^{b} \\
\pm 10.16\end{array}$ & $\begin{array}{c}277.50^{\mathrm{a}} \\
\pm 9.36\end{array}$ & $\begin{array}{c}268.30^{\mathrm{a}} \\
\pm 8.01\end{array}$ & $\begin{array}{l}235.30^{b} \\
\pm 10.44\end{array}$ & $*$ \\
\hline $6-12 \mathrm{Wks}$ & $\begin{array}{c}721.60^{b} \\
\pm 8.59 \\
\end{array}$ & $\begin{array}{l}865.50^{\mathrm{a}} \\
\pm 10.64 \\
\end{array}$ & $\begin{array}{c}836.20^{\mathrm{a}} \\
\pm 5.05 \\
\end{array}$ & $\begin{array}{c}761.00^{b} \\
\pm 9.58 \\
\end{array}$ & $*$ \\
\hline
\end{tabular}

a-c Means within a row with different superscripts are significantly different.

Nano-Se: Nanoselenium, Na-Se : Sodium selenite, NS: Not significant, *: $(\mathrm{P} \leq 0.05)$.

Organic selenium compared to the other groups (Table 2). These results are in disagreement with the findings of Ebeid et al. (2012) who showed that feeding rabbits on diets supplemented with organic Se at levels from 0.15 up to 0.30 ppm led to inferior feed conversion ratios compared with the control group. It has already been reported that the lifetime of the trypsin and peroxidase increases dramatically by interfacing them with nanomaterials. This ability to enhance these enzymes stability may impact the numerous biological processes such as digestion, metabolism and nutrient uptake (Sharma et al., 2007).From the economical point of view, the highest economic efficiency was recorded with rabbits received nano selenium followed by the rabbits received organic selenium compared to the other groups. This increment may be due to the improvement of weight gain as a result of increasing of feed intake, while the worst value was observed for those received inorganic selenium Table 3. 
Table 2: Effect of different sources of dietary Se on feed intake and feed conversion of growing NZW rabbits exposed to heat stress

\begin{tabular}{|c|c|c|c|c|c|}
\hline \multirow{2}{*}{ Items } & \multicolumn{5}{|c|}{ Treatment groups } \\
\hline & Control & Nano-Se & Organic Se & Na-Se & $\begin{array}{l}\text { Sig. } \\
\text { test }\end{array}$ \\
\hline \multicolumn{6}{|c|}{ Total Feed intake (g) } \\
\hline $6-8 \mathrm{Wks}$ & $783.90^{b} \pm 26.57$ & $1007.20^{\mathrm{a}} \pm 21.70$ & $983.75^{\mathrm{a}} \pm 23.56$ & $1054.49^{\mathrm{a}} \pm 21.04$ & \\
\hline $8-10 \mathrm{Wks}$ & $925.52+27.36$ & $983.26 \pm 32.69$ & $918.01+29.40$ & $946.93 \pm 27.84$ & NS \\
\hline $10-12 \mathrm{Wks}$ & $893.00 \pm 31.84$ & $897.30 \pm 39.12$ & $877.30 \pm 42.18$ & $864.50 \pm 42.36$ & $\mathrm{NS}$ \\
\hline 6-12 Wks & $2602.4^{\mathrm{b}} \pm 49.03$ & $2887.8^{\mathrm{a}} \pm 56.11$ & $2779.1^{\mathrm{ab}} \pm 52.62$ & $2865.3^{\mathrm{a}} \pm 54.24$ & \\
\hline \multicolumn{6}{|c|}{ Feed conversion (g feed/g gain) } \\
\hline $6-8 \mathrm{Wks}$ & $3.75^{\mathrm{a}} \pm 0.12$ & $3.36^{\mathrm{b}} \pm 0.07$ & $3.40^{\mathrm{b}} \pm 0.03$ & $4.00^{\mathrm{a}} \pm 0.14$ & $*$ \\
\hline 8 -10Wks & $3.49^{\mathrm{ab}} \pm 0.03$ & $3.42^{\mathrm{bc}} \pm 0.04$ & $3.29^{c} \pm 0.07$ & $3.58 \pm 0.04$ & $*$ \\
\hline $10-12 \mathrm{Wks}$ & $3.63^{\mathrm{a}} \pm 0.05$ & $3.23^{\mathrm{b}} \pm 0.07$ & $3.26^{\mathrm{b}} \pm 0.08$ & $3.65^{\mathrm{a}} \pm 0.07$ & $*$ \\
\hline 6-12 Wks & $3.60^{\mathrm{b}} \pm 0.04$ & $3.33^{\mathrm{c}} \pm 0.04$ & $3.32^{c} \pm 0.04$ & $3.76^{\mathrm{a}} \pm 0.05$ & $*$ \\
\hline \multicolumn{6}{|c|}{ Economical efficiency(\%) } \\
\hline 6-12 Wks & 0.9 & 1.1 & 1.1 & 0.6 & \\
\hline
\end{tabular}

a-c Means within a row with different superscripts are significantly different.

Nano-Se: Nanoselenium, Na-Se : Sodium selenite, NS: Not significant, *: $(\mathrm{P} \leq 0.05)$.

\section{Carcass traits:}

The effect of different Se sources on carcass traits is shown in Table 3. No significant differences in the percentages of heart, kidney, liver, dressed weight, fore part, intermediate part and hind part were found among all groups except the abdominal fat percentages. Carcass weight percentages (the weight of fore part and intermediate part) in rabbits received organic selenium and nano-Se were slightly higher in these rabbit groups except hind part with inorganic selenium and the control groups. The improvement in carcass weights could be attributed to the increase in the live body weight of rabbits. Abdominal fat was lower in rabbits received organic selenium followed by the animals received nano-Se as compared to inorganic selenium (sodium selenite) and the control groups. These results are in agreement with Ebeid et al. (2012) who show that feeding rabbits on diets supplemented with organic Se at levels from 0.15 up to $0.30 \mathrm{ppm}$ led to an increasing in both hot carcass weight and dressing percentage compared with the control group. Saleh et al. (2013) also, reported that carcass weight, dressing percentage and liver weight were increased; while, abdominal fat weight was decreased by dietary 
Table 3: Effect of different sources of dietary Se on carcass traits of growing NZW rabbits exposed to heat stress

\begin{tabular}{|l|c|c|c|c|c|}
\hline \multirow{2}{*}{ Items } & \multicolumn{5}{|c|}{ Treatment groups } \\
\cline { 2 - 6 } & Control & Nano-Se & Organic Se & Na-Se & Sig. test \\
\hline Pre slaughter Wt. & $1370.00^{\mathrm{d}} \pm 7.12$ & $1553.33^{\mathrm{a}} \pm 5.81$ & $1510.00^{\mathrm{b}} \pm 5.77$ & $1472.33^{\mathrm{c}} \pm 6.22$ & $*$ \\
\hline Heart, \% & $0.294 \pm 0.001$ & $0.297 \pm 0.002$ & $0.299 \pm 0.002$ & $0.298 \pm 0.002$ & NS \\
\hline Liver, \% & $2.75 \pm 0.01$ & $2.77 \pm 0.01$ & $2.76 \pm 0.01$ & $2.75 \pm 0.02$ & NS \\
\hline Kidney, \% & $0.75 \pm 0.01$ & $0.76 \pm 0.01$ & $0.78 \pm 0.01$ & $0.78 \pm 0.01$ & NS \\
\hline Abdominal fat, \% & $2.35^{\mathrm{a}} \pm 0.01$ & $1.96^{\mathrm{bc}} \pm 0.11$ & $1.85^{\mathrm{c}} \pm 0.09$ & $2.13^{\mathrm{ab}} \pm 0.05$ & $*$ \\
\hline Dressed weight, \% & $58.21 \pm 3.97$ & $58.05 \pm 3.94$ & $58.11 \pm 3.95$ & $58.08 \pm 3.94$ & NS \\
\hline Fore part \% & $30.67 \pm 3.14$ & $31.25 \pm 4.25$ & $34.53 \pm 4.03$ & $32.43 \pm 5.60$ & NS \\
\hline Intermediate part, \% & $30.41 \pm 1.43$ & $31.20 \pm 2.44$ & $30.90 \pm 2.17$ & $29.27 \pm 3.24$ & NS \\
\hline Hind part, \% & $38.92 \pm 3.32$ & $37.55 \pm 4.76$ & $34.57 \pm 4.35$ & $38.30 \pm 4.43$ & NS \\
\hline
\end{tabular}

a-c Means within a row with different superscripts are significantly different.

Nano-Se: Nanoselenium, Na-Se : Sodium selenite, NS: Not significant, *: $(\mathrm{P} \leq 0.05)$.

supplementation of organic selenium. Dokoupilova et al. (2007), reported that dressing-out percentage of growing rabbits did not affect by adding $\mathrm{Se}$ (Seenriched yeast). The improvement in the performance of rabbits due to $\mathrm{Se}$ supplementation may be due to that decreases the oxidative stress and helps in the scavenging of ROS from the tissues, because Se is a cofactor for many antioxidant enzymes such as glutathione peroxidase and thioredoxin reductase (El-Batal et al., 2012).

The effect of different Se sources on chemical composition (moisture, protein percentages, fat and ash) of hind leg meat is shown in Table 4. The results show significant differences for fat and protein percentage. Treatment with different Se sources caused significant increase in protein percentage as compared with control. The hind leg meat of rabbits fed Se contained less fat than that of control rabbits. These results are in agreement with the findings of Tatli and Seven, (2009). Dietary selenium intake may changes the energy metabolism through AMP-activated protein kinase (AMPK) which is a sensor of energy status that controls cellular energy homeostasis (He et al., 2016), therefore, high intake of energy led to increase total body protein deposition rate. Se supplementation had no effect on the moisture and ash concentration of hind leg meat (Table 4).

The effect of different Se sources on water holding capacity (WHC) of hind leg meat is shown in Table 4. The treatment groups with different Se sources caused significantly to increase in WHC as compared with control. 
Table 4: Effect of different sources of dietary Se on chemical composition and meat quality of rabbit exposed to heat stress

\begin{tabular}{|c|c|c|c|c|c|}
\hline \multirow[b]{2}{*}{ Items } & \multicolumn{5}{|c|}{ Treatment groups } \\
\hline & Control & Nano-Se & $\begin{array}{c}\text { Organic } \\
\text { Se }\end{array}$ & Na-Se & $\begin{array}{l}\text { Sig. } \\
\text { test }\end{array}$ \\
\hline Mosture \% & $\begin{array}{l}70.72 \\
\pm 0.12\end{array}$ & $\begin{array}{l}70.67 \\
\pm 0.13\end{array}$ & $\begin{array}{l}70.65 \\
\pm 0.11\end{array}$ & $\begin{array}{l}70.75 \\
\pm 0.11\end{array}$ & NS \\
\hline Crude protein \% & $\begin{array}{c}19.43 \mathrm{c} \\
\pm 0.24\end{array}$ & $\begin{array}{c}21.12 \mathrm{a} \\
\pm 0.13\end{array}$ & $\begin{array}{c}20.96 \mathrm{a} \\
\pm 0.09\end{array}$ & $\begin{array}{c}20.51 \mathrm{~b} \\
\pm 0.08\end{array}$ & $*$ \\
\hline Ether Extract \% & $\begin{array}{l}6.57 \mathrm{a} \\
\pm 0.11\end{array}$ & $\begin{array}{l}4.26 \mathrm{c} \\
\pm 0.08\end{array}$ & $\begin{array}{c}4.47 \mathrm{bc} \\
\pm 0.11\end{array}$ & $\begin{array}{c}4.64 \mathrm{~b} \\
\pm 0.10\end{array}$ & $*$ \\
\hline Ash \% & $\begin{array}{l}1.86 \\
\pm 0.54\end{array}$ & $\begin{array}{c}1.92 \\
\pm 0.22\end{array}$ & $\begin{array}{c}1.91 \\
\pm 0.18\end{array}$ & $\begin{array}{c}2.05 \\
\pm 0.18\end{array}$ & NS \\
\hline Water-holding capacity \% & $\begin{array}{l}50.72 \mathrm{c} \\
\pm 0.12 \\
\end{array}$ & $\begin{array}{c}60.83 \mathrm{a} \\
\pm 0.20 \\
\end{array}$ & $\begin{array}{l}60.66 \mathrm{a} \\
\pm 0.17 \\
\end{array}$ & $\begin{array}{c}55.94 b \\
\pm 0.15\end{array}$ & $*$ \\
\hline Selenium concentration $\mu \mathrm{g} / \mathrm{g}$ & $\begin{array}{c}0.09 \mathrm{c} \\
\pm 0.001\end{array}$ & $\begin{array}{l}0.54 \mathrm{a} \\
\pm 0.01\end{array}$ & $\begin{array}{r}0.52 \mathrm{a} \\
\pm 0.01\end{array}$ & $\begin{array}{l}0.47 \mathrm{~b} \\
\pm 0.01\end{array}$ & $*$ \\
\hline $\mathrm{mg}$ MDA/kg at Od & $\begin{array}{l}2.31 \mathrm{a} \\
\pm 0.04\end{array}$ & $\begin{array}{l}1.22 \mathrm{~b} \\
\pm 0.09\end{array}$ & $\begin{array}{l}1.29 \mathrm{~b} \\
\pm 0.11\end{array}$ & $\begin{array}{l}1.41 \mathrm{~b} \\
\pm 0.12\end{array}$ & $*$ \\
\hline mg MDA/kg at $6 d$ & $\begin{array}{r}2.70 \mathrm{a} \\
\pm 0.12 \\
\end{array}$ & $\begin{array}{l}1.50 \mathrm{c} \\
\pm 0.10 \\
\end{array}$ & $\begin{array}{l}1.62 b c \\
\pm 0.04 \\
\end{array}$ & $\begin{array}{r}1.84 \mathrm{~b} \\
\pm 0.07 \\
\end{array}$ & $*$ \\
\hline mg MDA/kg at 12d & $\begin{array}{l}3.28 \mathrm{a} \\
\pm 0.14\end{array}$ & $\begin{array}{l}1.96 \mathrm{~b} \\
\pm 0.17\end{array}$ & $\begin{array}{l}2.03 \mathrm{~b} \\
\pm 0.17\end{array}$ & $\begin{array}{l}2.29 b \\
\pm 0.20\end{array}$ & $*$ \\
\hline
\end{tabular}

a-c Means within a row with different superscripts are significantly different.

Nano-Se: Nanoselenium, Na-Se : Sodium selenite, NS: Not significant, *: $(\mathrm{P} \leq 0.05)$.

The results are in agreement with Cardinali et al. (2015) who reported that supplementation of some antioxidants to rabbit rations increased meat WHC. This marked increase in WHC was probably related to the positive effect of Se as antioxidants on the integrity of muscle fibers, thereby enhancing their capability to retain water (Stanley 1991).

The effect of different Se sources on selenium concentration of hind leg meat is shown in Table 4. Selenium concentration was higher significantly in all groups of received selenium than in the control group. These results are in agreement with the results of Dokoupilová et al. (2007) who concluded that rabbits fed with organic Se was effective in retain of selenium in the meat tissues. These effects could act as a positive factor in order to improve rabbit meat consumption, turning it into a healthy food for human (Hernanández and Gondret, 2006). Selenium feeding as nano-Se and organic forms results in 
higher tissue selenium concentrations than selenium feeding in the form of selenite. This has also been shown in pigs (Zhan et al., 2007) and chickens (Payne and Southern, 2005).

The effect of different Se sources on lipid oxidation of hind leg meat at different time storage is shown in Table 4. Treatment groups with different $\mathrm{Se}$ sources caused significantly to decrease in TBARS levels as compared with control group.

Thiobarbituric acid-reactive substances (TBARS) production was measured in the hind leg meat, which is more susceptible to oxidative deterioration due to its higher fat content. Lipid oxidation and discoloration are storage believed to be major causes of quality deterioration in meat during refrigerated storage.

The level of oxidation after refrigerated storage of rabbit leg meat has been studied by Hernández et al. (2008). They found that oxidative products were not very high in rabbit meat after refrigerated storage. However, there has been an increasing interest in using antioxidants in rabbit feeds to produce meat with high oxidative stability. These observations are consistent with those of LópezBote et al., (1998) who found that meat lipid oxidative stability was improved by increasing the level of antioxidant efficiency oats in rabbit diet. Also, vitamin $\mathrm{E}$ has also been effective in reducing lipid oxidation during refrigerated and frozen storage of meat (Lo Fiego et al., 2004).

\section{Serum antioxidative status}

Rabbits exposure to heat stress resulted in significant decrease in serum total antioxidant capacity and elevated serum malondialdehyde (MDA) which was obtained in the control group. However, rabbits receiving different sources of Se in the present study appeared to antagonize the effect of heat stress (Table 5 ). The total antioxidant capacity in blood serum of rabbits received nano-Se and those received organic selenium was significantly increased compared to the control and Se selenite groups. However, these treatments significantly reduced lipid peroxidation in serum expressed as serum MDA in comparison with the other groups. Similar to our finding, several studies showed that heat stress causes oxidative stress into tissue via increasing lipid peroxidation (MDA) Kim et al., (2010). Also, dietary organic selenium at different levels in rabbits showed a positive effect on total antioxidant capacity compared with control group (Abdulkareem, 2011). Also, the finding of this study is consistent with findings 
of Zeweil et al. (2016) who showed that exposing growing rabbits to high temperature conditions during summer season resulted in significant decrease in serum total antioxidant capacity which was obtained in the control group, These results could be suggested that dietary addition of selenium decrease the oxidative stress level caused by heat stress.

\section{Total DNA, RNA, and total protein contents:}

The effect of Se source on total DNA, RNA, and total protein contents in rabbit blood are summarized in Table 5. The current results in the present study show that the values recorded for total DNA, RNA, and protein contents were significantly reduced in the control group compared with animals receiving different sources of Se. A highly significant increase was observed in nano-Se group followed by organic selenium group as compared to control and inorganic Se groups. These results are in agreement with those of Mostafa et al. (2009) who reported that hyperthermia has been shown to induce a number of effects in mammalian cells including inhibition of DNA, RNA, and protein synthesis. This finding could be explained by the over production of ROS free radical chain reactions which can cause oxidative damage to proteins and DNA (Stocker and Keaney 2004).

Table 5: Effect of different sources of dietary Se on serum antioxidative status, tissue protein and nucleic acid of growing NZW rabbits exposed to heat stress

\begin{tabular}{|c|c|c|c|c|c|}
\hline \multirow{2}{*}{ Items } & \multicolumn{5}{|c|}{ Treatment groups } \\
\hline & Control & Nano-Se & Organic Se & Na-Se & Sig. test \\
\hline $\begin{array}{l}\text { Total antioxidant } \\
\text { capacity } \mathrm{mM} / \mathrm{L}\end{array}$ & $\begin{array}{l}0.91^{\mathrm{b}} \\
\pm 0.01\end{array}$ & $\begin{array}{l}1.56^{\mathrm{a}} \\
\pm 0.11\end{array}$ & $\begin{array}{l}1.38^{\mathrm{a}} \\
\pm 0.13\end{array}$ & $\begin{array}{l}0.99^{\mathrm{b}} \\
\pm 0.01\end{array}$ & * \\
\hline $\begin{array}{l}\text { Malondialdehyde } \\
\text { (MDA) nmol/ml }\end{array}$ & $\begin{array}{l}6.87^{\mathrm{a}} \\
\pm 0.22\end{array}$ & $\begin{array}{l}3.62^{\mathrm{b}} \\
\pm 0.16\end{array}$ & $\begin{array}{l}3.70^{\mathrm{b}} \\
\pm 0.11\end{array}$ & $\begin{array}{l}6.02^{\mathrm{a}} \\
\pm 0.19\end{array}$ & $*$ \\
\hline DNA in tissue (mg/g) & $\begin{array}{l}0.37^{\mathrm{c}} \\
\pm 0.02\end{array}$ & $\begin{array}{l}0.42^{\mathrm{a}} \\
\pm 0.01\end{array}$ & $\begin{array}{l}0.41^{\mathrm{a}} \\
\pm 0.02\end{array}$ & $\begin{array}{l}0.39^{\mathrm{b}} \\
\pm 0.04\end{array}$ & * \\
\hline RNA in tissue (mg/g) & $\begin{array}{l}0.22^{\mathrm{c}} \\
\pm 0.007\end{array}$ & $\begin{array}{l}0.27^{\mathrm{a}} \\
\pm 0.001\end{array}$ & $\begin{array}{l}0.27^{\mathrm{a}} \\
\pm 0.001\end{array}$ & $\begin{array}{l}0.26^{\mathrm{b}} \\
\pm 0.01\end{array}$ & $*$ \\
\hline $\begin{array}{l}\text { Total protein in tissue } \\
(\mathrm{g} / \mathrm{g})\end{array}$ & $\begin{array}{l}5.70^{\mathrm{b}} \pm \\
0.14\end{array}$ & $\begin{array}{l}7.09^{\mathrm{a}} \\
\pm 0.31\end{array}$ & $\begin{array}{l}7.04^{\mathrm{a}} \\
\pm 0.20\end{array}$ & $\begin{array}{r}7.03^{\mathrm{a}} \\
\pm 0.22\end{array}$ & $*$ \\
\hline
\end{tabular}

a-c Means within a row with different superscripts are significantly different.

Nano-Se: Nanoselenium, Na-Se : Sodium selenite, NS: Not significant, *: $(\mathrm{P} \leq 0.05)$. 
Aggregation of oxidative damaged DNA could lead to a reduced mRNA expression and protein production during heat stress (Shin et al., 2008). It well known that RNA is necessary for protein synthesis. The treatment of Se improved total DNA content, which could be attributed to the mechanism of chemo protection of selenium that related to its antioxidant properties as well as its ability to interfere with DNA repair pathways (Kara et al., 2007).

\section{Chromosomal aberrations of bone marrow cells:}

The effects of Se source on chromosomal aberrations of bone marrow cells in rabbit are summarized in Table 6. Data in Table 6 show various types of structural chromosomal aberrations which consisted of gaps, breaks, deletions and centromeric attenuations, fragmentation and toral aberration as affected by heat stress. The percentage of aberrations in bone marrow was significantly cause to reduce in all groups of rabbit treated with selenium. Our results in agreement with Yamada et al. (1989) and Waissenbourn and Obe, (1992) who reported that high temperature $\left(41.5^{\circ} \mathrm{C}\right.$ and $43{ }^{\circ} \mathrm{C}$ respectively) led to structural chromosome aberrations (breaks, stickiness, fragmentation). Heat may induce DNA base damage indirectly via protein damage (Takahashi, et al., 2004) and changes in enzyme complexes for DNA synthesis and repair (Streffer, 1995). The compounds that have antioxidant properties are known to produce anti-genotoxic effect by reducing toxic free radicals (Dusinska et al., 2003). Furthermore, the protective effect of selenium against the mutagenic effect, and the protective role of selenium might be related to its antioxidant effect.

In this study, although nano-Se followed by organic selenium could alleviate the negative effect of heat stress, sodium selenite at the same concentration $(0.3 \mathrm{ppm})$ was less efficiency in this concern.

This difference might be due to the difference in absorption efficiency of nano-Se and sodium selenite. Hu et al. (2012) showed that absorption of nanoSe from the intestinal lumen into the body was higher than that of sodium selenite, while intestinal retention of nano-Se was lower than that of sodium selenite. The authors added that the organic selenium in selenium yeast is actively absorbed from the intestine via the $\mathrm{Na}+$ dependent neutral amino acid pathway (Schrauzer, 2000).

Generally, the Se nanoparticles used in the present study were spherical in shape and had a size less than $100 \mathrm{~nm}$ according to Eszenyi et al. (2011). The nanoparticles of this size show high antioxidant activity (Torres et al., 
Table 6: Effect of different sources of dietary Se on chromosomal aberrations in bone marrow cells of rabbits exposed to heat stress

\begin{tabular}{|l|c|c|c|c|c|}
\hline \multirow{2}{*}{ Items } & \multicolumn{5}{|c|}{ Treatment groups } \\
\cline { 2 - 6 } & Control & Nano-Se & Organic Se & Na-Se & Sig. test \\
\hline \multirow{2}{*}{ Gap } & $2.28^{\mathrm{a}}$ & $1.58^{\mathrm{c}}$ & $1.71^{\mathrm{bc}}$ & $1.94^{\mathrm{b}}$ & $*$ \\
& \pm 0.04 & \pm 0.08 & \pm 0.09 & \pm 0.08 & \\
\hline \multirow{2}{*}{ Break } & $2.87^{\mathrm{a}}$ & $1.53^{\mathrm{c}}$ & $1.64^{\mathrm{bc}}$ & $1.84^{\mathrm{b}}$ & $*$ \\
& \pm 0.05 & \pm 0.08 & \pm 0.01 & \pm 0.07 & \\
\hline \multirow{2}{*}{ Centromere attenuation } & $2.95^{\mathrm{a}}$ & $1.47^{\mathrm{c}}$ & $1.49^{\mathrm{c}}$ & $1.89^{\mathrm{b}}$ & $*$ \\
& \pm 0.07 & \pm 0.10 & \pm 0.10 & \pm 0.07 & \\
\hline \multirow{2}{*}{ Deletion } & $0.75^{\mathrm{a}}$ & $0.26^{\mathrm{c}}$ & $0.28^{\mathrm{bc}}$ & $0.31^{\mathrm{b}}$ & $*$ \\
& \pm 0.01 & \pm 0.01 & \pm 0.01 & \pm 0.007 & \\
\hline
\end{tabular}

a-c Means within a row with different superscripts are significantly different.

Nano-Se: Nanoselenium, Na-Se : Sodium selenite, NS: Not significant, *: $(\mathrm{P} \leq 0.05)$.

2012) and have an increased ability to trap free radicals with greater antioxidant effect (Huang et al., 2003), and have an increased adsorptive ability due to interactions between the nanoparticles and $\mathrm{NH}, \mathrm{C}=\mathrm{O}, \mathrm{COO}-$, and $\mathrm{C}-\mathrm{N}$ functional groups of proteins (Zhang et al., 2004). Additionally, nano-Se can act as a chemopreventive agent when administered at a smaller particle size (Peng et al., 2007).

\section{CONCLUSION}

This study clearly indicates that heat stress has a pro-oxidant characters and its administration is associated with induction of oxidative stress by the generation of free radicals that affect anti-oxidative system, as well as, decreased total antioxidant capacity with increase in MDA content leading to cytotoxicity. In addition, heat stress decreased total nucleic acids and liver protein contents. Co-administration of organic or inorganic selenium or selenium nano- particles (SeNps) ameliorates these disturbances and reduces the damage resulting from interaction between ROS and protein, RNA and DNA molecules.

These results could be attributed to their antiradical /antioxidant efficacy. Moreover, the data showed that the use of nano-Se appeared to be more effective than organic or inorganic selenium in attenuating the undesirable effects of heat stress and it has attracted a wide spread attention due to its high bioavailability, low toxicity and antioxidant activity. 
INFLUENCE OF INGESTION OF NANO-SELENIUM ON RABBITS

\section{REFERENCES}

A.O.A.C. (2001). Official Methods of Analysis. 13th edition, Association of Official Analytical Chemists, Washington D. C.

Bregman, A. A. (1983). Laboratory Investigations And Cell Biology. New York: John Willey and Sons; 51-60.

Brown, M.W. and J.H. Watkinson (1977). An automated fluorimetric method for the determination of nanogram quantities of selenium. Anal. Chim. Acta, 89, 29-35.

Cardinali, R.; M. Cullere; A. Dal Bosco; C. Mugnai; S. Ruggeri; S. Mattioli; C. Castellini; M. TrabalzaMarinucci; A.Dalle Zotte (2015). Oregano, rosemary and vitamin $\mathrm{E}$ dietary supplementation in growing rabbits: Effect on growth performance, carcass traits, bone development and meat chemical composition, Livest Sc. $i ; 175: 83-9$.

Dokoupilová, A.; M. Marounek; V. Skřivanová; P. Březina (2007). Selenium content in tissues and meat quality in rabbits fed selenium yeast. Czech J. Anim. Sci., 52: 165-169

Duncan, D. B. (1955). Multiple Ranges and Multiple F Test. Biometrics, 11: 1 -42.

Dusinska, M.; A. Kazimirova; M. Barancokova; M. Beno; B. Smolkova; A. Horska; K. Raslova; L. Wsolova and A. Collins (2003). Nutritional supplementation with antioxidants decreases chromosomal damage in humans. Mutagen, 18:371-376.

Ebeid, T.; H. Zeweil; M. Basyony and H. Badry (2012). The impact of incorporation of organic selenium into meat on growth performance, antioxidative status, and immue response in growing rabbits. In: Proc. Of the $10^{\text {th }}$ World Rabbit Congress, September 3-6, Sharm El-Sheikh, Egypt, pp. 861-864.

Edens, F. W. (2002). Practical applications for selenomethionine: broiler breeder reproduction. In: Biotechnology in the Feed Industry. Proceedings of Alltech are the $18^{\text {th }}$ Annual Symposium, Edited by Lyons, T. P. and K. A. Jacques, Nottingham University Press, Nottingham, UK. 29 -42.

El-Batal, A.I.; Abou Zaid O.; Noaman E; and ES. Ismail (2012). Promising antitumor activity of fermented wheat germ extract in combination with selenium nano-particles. Int. J. Pharm. Health Care.; 2(6): 1-22. 
Eszenyi, P.; A. Sztrik; B. Babka and J. Prokisch (2011). Elemental, nano-sized $(100-500 \mathrm{~nm})$ selenium production by probiotic lactic acid bacteria. International Journal of Bioscience, Biochemistry and Bioinformatics, 1: 148-152.

Evans, E.P. (1987): karyotyping and sexing of garnets and embryos and fetuses and in situ hybridization to chromosomes. In mammalian development. Practical Approach, Non K, M.(Ed), bl. IRL, Press, Oxford, pp.93:100.

Gao, X.Y.; J. Zhang and L. Zhang (2002). Hollow sphere selenium nanoparticles: there in vitro anti hydroxyl radical effect. Adv. Mater., 14: 290-293.

Habeeb, A.A.M.; A.I. Aboul-Naga and A.F. Khadr (1999). Deteriorationeffect of summer hot climate on bunnies of acclimatized rabbits during suckling period. In: $1^{\text {st }}$ International Conference on Indigenous versus Acclimatized Rabbits, El-Arish, North Sinai, Egypt, 253-263.

Habeeb, A.A.M.; A.M. El-Maghawry; I.F.M. Marai and A.E. Gad (1998). Physiological thermoregulation mechanism in rabbits drinking saline water under hot summer conditions. In: $1^{\text {st }}$ International Conference on Indigenous versus Acclimatized Rabbits, El-Arish, North Sinai, Egypt, 443456.

He, S. X. Guo; W. Tan; X. Su; J. Li; W. Pan and H. Qiu (2016). Effect of Selenium Deficiency on Phosphorylation of the AMPK Pathway in Rats. Biol. Trace Elem Res. Feb;169(2):254-60

Hernández, P.; V. Cesari and A. Blasco (2008). Effect of genetic rabbit lines on lipid content, lipolytic activities and fatty acid composition of hind leg meat and perirenal fat. Meat Sci., 78, 485-491.

Hernández, P. and F. Gondret (2006). Rabbit Meat Quality. In: Maertens L., Coudert P. (Eds.). Recent Advances in Rabbit Sciences. ILVO, Merelbeke, Belgium, 269-290.

Hu, H.C.; Y.L. Li; L. Xiong Zhang; J. Song and MS. Xia (2012). Comparative effects of nano elemental selenium and sodium selenite on selenium retention in broiler chickens. Animal Feed Science and Technology, 177: 204-210.

Huang, B.; J. Zhang; J. Hou and C. Chen (2003). Free radical scavenging efficiency of Nano-Se in vitro. Free Radical Biology and Medicine, 35: 805-813. 
Kara, H.; A.Cevik; V. Konar; A. Dayangac; and M. Yilmaz (2007). Protective effects of antioxidants against cadmium-induced oxidative damage in rat testes. Biol Trace Elem Res.; 120(1-3): 205-11.

Kermauner, A. and A. Laurenčič (2008). Supplementation of rabbit diet with chestnut wood extract: Effect on in vitro gas production from two sources of protein. In Proc.: 9th World Rabbit Congr. Verona Jun., 10-13, 689-693.

Kim, T. S.; C. L. Liu; M. Yassour; J. Holik; N. Friedman; S. Buratowski and O. J. Rando (2010). RNA polymerase mapping during stress responses reveals widespread nonproductive transcription in yeast. Genome Biol. , 11, R75.

Kumar, S. and BV. Kumar Ajeet (2011). Review: Effect of heat stress in tropical livestock and different strategies for its amelioration. Journal of Stress Physiology \& Biochemistry;7(1):45-54.

Lo Fiego, D.P.; P. Santero; P. Macchioni; D. Mazzoni; F. Piattoni; F. Tassone; E. De Leonibus (2004). The effect of dietary supplementation of vitamins $\mathrm{C}$ and $\mathrm{E}$ on the a-tocopherol content of muscles, liver and kidney, on the stability of lipids, and on certain meat quality parameters of the longissimus dorsi of rabbits. Meat Sci., 67, 319-327.

López-Bote, C.J.; M. Sanz; A. Rey; A. Castaño and J. Thos (1998). Lower oxidation in the muscle of rabbits fed diets containing oats. Anim. Feed Sci. Tech., 70, 1-9.

Lowry, O.H.;NJ. Rosebrough; AL. Farr and RJ. Randall (1951). Protein measurement with the Folin phenol reagent. J. Biol. Chem.; 193: 265-275.

Mostafa, S.I.; M.F.F. Bayomy; I.H. Amal and N.A.R.M. Zahran (2009). Effect of experimental mild and severe whole body hyperthermia. Egypt. J. Med. Lab. Sci., 18(1):1-17.

NRC (1977). National Research Council: Nutrient Requirements of Rabbits. 2nd Revised Edition, National Academy of Sciences, Washington, DC. USA.

Okab, AB.; SG. El-Banna and AA. Koriem (2008). Influence of environmental temperatures on some physiological and biochemical parameters of male New-Zealand rabbits. Slovak Journal of Animal Science, 41, 12-19.

Payne, R.L. and L.L. Southern (2005). Comparison of inorganic and organic selenium sources for broilers. Poultry Sci., 84: 898-902.

Peng, D.; J. Zhang; Q, Liu and EW.Taylor (2007). Size effect of elemental selenium nanoparticles (Nano-Se) at supra nutritional levels on selenium accumulation and glutathione S-transferase activity. Journal of Inorganic Biochemistry, 101: 1457-1463. 
Piette, G.; and Y. Raymond (1999): Vergleichende bewertung verschiedener methoden. Bestimmung der Ranzigkeit in Fleischprodukten. Fleischwirtschaft, 7, 69-73.

Preter, F.S. (2000). Organic Selenium: Benefits To Animal And Humans, A Biochemist's View. In: Proceedings of Alltech's 16th symposium. Nottingham University Press, Nottingham, pp: 205-213.

Raya, A. H.; A. M. Abbas and M. A. A. Hussein (1991). Comparative studies on the efficiency of some plant protein sources to replace soybean meal in rations for broiler chick's performance and economic efficiency. J. of Agr. Sci. Mansoura University, 16: 2514-2527.

Rayman, M.P. (2004). The use of high-selenium yeast to raise selenium status: How does it measure up? Br. J. Nutr., 92, 557-573.

Saleh, A.; T. A. Ebeid and Y. Z. Eid (2013). The Effect of Dietary Linseed Oil and Organic Selenium on Growth Performance and Muscle Fatty Acids in Growing Rabbits. Pak. Vet. J., 33(4): 450-454.

SAS (2001). SAS User's guide: Statistics. Version 9th Ed. SAS Institute Inc.; Cary N.C.; USA.

Schrauzer, G.N. (2000). Selenomethionine: A review of its nutritional significance, metabolism, and toxicity. J. Nutr., 130: 1653-1656.

Sharma, A.; Y. Qiang; J. Antony; D. Meyer; P. Kornacki and A. Paszczynski (2007). Dramatic Increase in Stability and Longevity of Enzymes Attached to Monodispersive Iron Nanoparticles. Magnetics, IEEE Transactions, 43: 2418-2420.

Shin, M. H.; Y. J. Moon; J. E. Seo; Y. Lee; K. H. Kim and J. H. Chung (2008). Reactive oxygen species produced by NADPH oxidase, xanthine oxidase, and mitochondrial electron transport system mediate heat shock-induced MMP-1 and MMP-9 expression. Free Radic Biol Med; 44:635-645.

Sendcor, G. W. and Cochran, W. G. (1982). Statistical Methods $2^{\text {nd }}$ Edition. Lowa University., press. Ames., Iowa.

Stanley, DW. (1991). Biological membrane deterioration and associated quality losses in food tissues. Crit Rev Food Nutr.; 30:487-553.

Stocker, R. and J. F. Keaney (2004). Role of oxidative modifications in atherosclerosis. Physiol Rev 84: 1381-1478.

Streffer, C. (1995): Molecular and cellular mechanisms of hyperthermia. In Seegenschmiedt MH, Fessenden P, Vernon CC (eds): Thermoradiotherapy and Thermochemotherapy, Volume 1. Berlin: Springer Verlag. 
Takahashi, A.; H. Matsumoto; K. Nagayama; M. Kitano; S. Hirose; H. Tanaka; E. Mori; N. Yamakawa; J. Yasumoto; K. Yuki; K. Ohnishi and T. Ohnishi (2004). Evidence for the involvement of double-strand breaks in heat-induced cell killing. Cancer Res., 64:8839- 8845.

Tatl S. P. and I. Seven (2009). Effects of selenium and vitamin c supplemented with high energy diet on the performance of broilers in cold $(15 \mathrm{oc})$ environment. Bulgarian Journal of Veterinary Medicine, 12, No 1, 25-32

Torres, SK; VL. Campos; CG. Leon; SM. Rodriguez-Lamazares; SM. Rojas; M. Gonzalez; C. Smith and MA. Mondaca (2012). Biosynthesis of selenium nanoparticles by Pantoeaagglomerans and their antioxidant activity. Journal of Nanoparticle Research, 14: 1236-1245..

Waissenbourn, U. and G. Obe, (1992). Modification of bleomycin induced chromosome aberration by hyperthermia and under energy depleting conditions in human peripheral lymphocytes. Int. J. Radiat. Biol., 62: 289-296.

Wang, H.; J. Zhang and H. Yu, (2007). Elemental selenium at nano size possesses lower toxicity without compromising the fundamental effect on selenoenzymes: comparison with selenomethionine in mice. Free Radical Biol. Med., 42: 524-533.

Yamada, K.; Y. Ichikawa; H. Okumura (1989): Effects of high temperatures on chromosomes of normal and transformed human cell. Human Cell, 2, $80-85$.

Zeweil, H. S.; S. M. Zahran; M. H. Ahmed; Y. El- El-Gindy and W. G. M. Shaglouf (2016). Effects of allicin and lycopene on performance, carcass, hematological profile and antioxidant status of growing rabbits through summer season. Journal of the Advances in Agriculture Research, (Under publication).

Zhan, X.A.; M. Wang; R.Q. Zhao; W.F. Li and Z.R. Xu (2007). Effects of different selenium source on selenium distribution, loin quality and antioxidant status in finishing pigs. Anim. Feed Sci. Technol., 132: 202-211.

Zhang, W.; Z, Chen; H. L. Liu Zhang; P. Gaoa and D. Li (2011). Biosynthesis and structural characteristics of selenium nanoparticles by Pseudomonas alcaliphila. Coll Surf B.; 88:196-201.

Zhang, Y.; J. Zhang; HY. Wang and HY. (2004). Chen Synthesis of selenium nanoparticles in the presence of polysaccharides. Materials Letters, 58: 2590-2594. 
Zhang, J.S.; X.Y. Gao; L.D. Zhang and Y.P. Bao (2001). Biological effects of nano red elemental selenium. Biofactors, 15: 27-38.

Zhang, J.S.; H.L. Wang; X.X. Yan and L.D. Zhang (2005). Comparison of short term toxicity between Nano-Se and selenite in mice. Life Sci., 76: 1099-1109.

\section{تاثير النانو سيلينيوم على كفاءة النمو والحالة التاكسدية والوراثة الخلوية فى الارانب النيوزليندى الابيض}

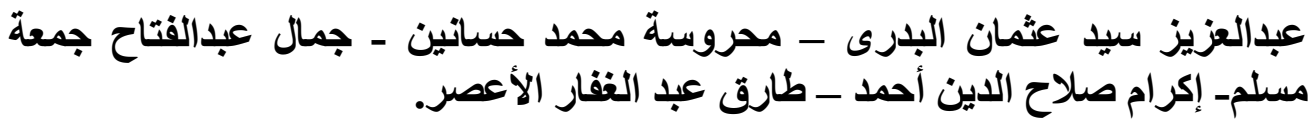

الإجهاد الحراري هو واحد من العديد من المشاكل التي تواجه انتاج الأرانب. تم

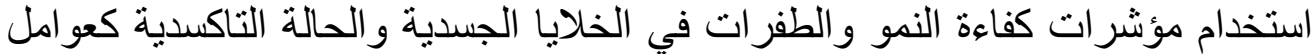

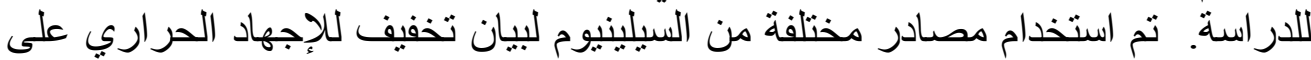

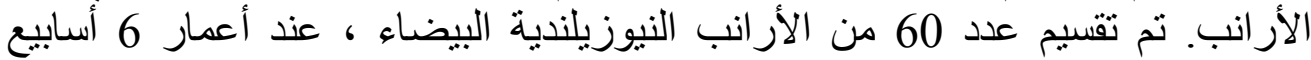

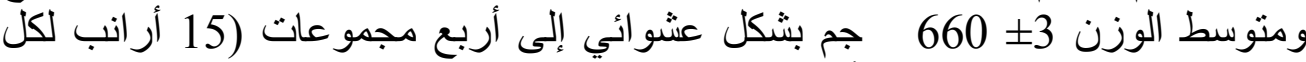

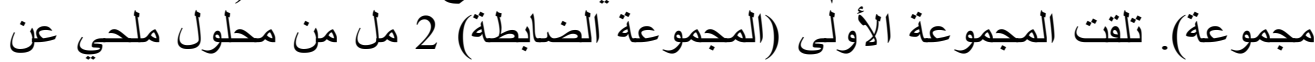

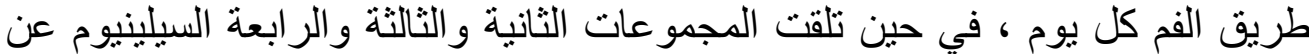

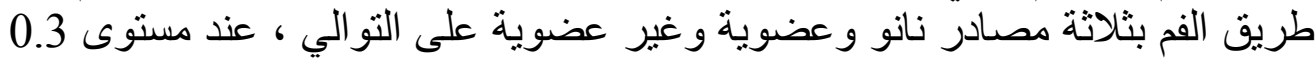
ملجم / كجم من وزن الجسم كل يوم باستخدام انبوبة خاصة. تم حل هذه المصادر في 2

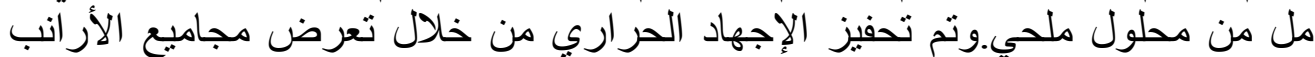

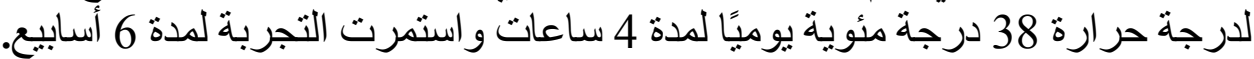

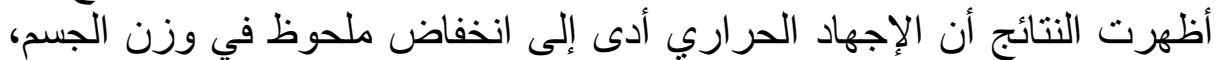

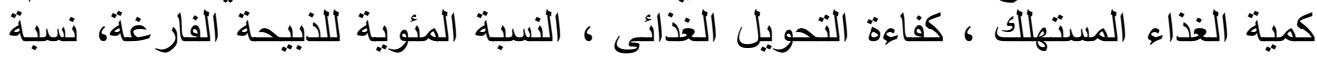

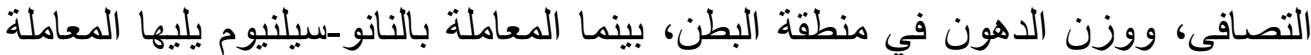

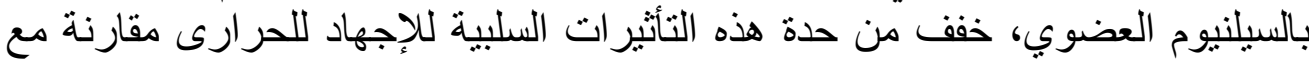
تللك المعاملة بالسيلنيوم غير العضوي، (فيلى صورة سلينات الصوديم) ومجمو عة الكنترول. أيضا تسبب الإجهاد الحراري زيادة في الثذوذ الكرومسومى، فضلفالف عن أنه أدى إلى 
انخفاض تركيز الحضض النووي والبروتين فى الخلايا. بالإضافة إلى ذللك، فقد خفضت

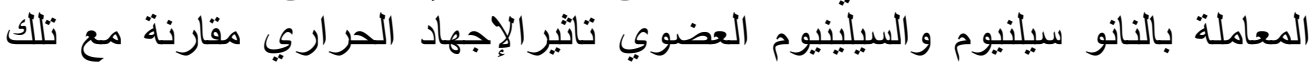

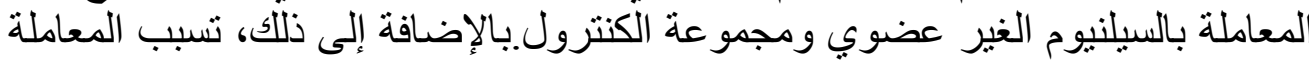

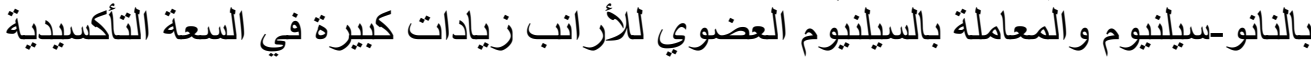

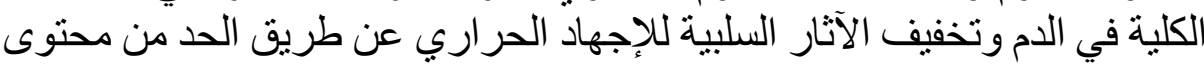
malondialdehyde التوصية: نخلص من هذه الدراسة ، بان المعاملة بالنانو-سيلنيوم او المعاملة بالسيلنيوم

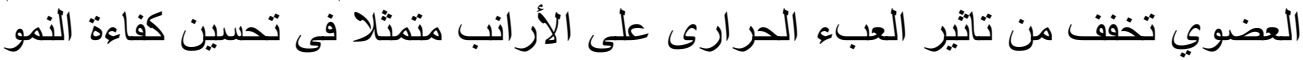
وخف الثذوذ الكرومسومى وتركيز الاحماض النووية و البروتين والحالة التاكسدية. 